\title{
Reforma Administrativa, face à mudança da Capital Federal
}

$35(81) .076$

$N_{0}$

OSSA estrutura administrativa se assenta muito no tipo centralizado, na excessiva dependência da ação đireta do Chefe da $\mathrm{Na-}$ ção. De um modo geral, as decisões finais carecem de imediata ação de uma só pessoa, atribuindo uma responsabilidade de tal ordem que redunda em irresponsabilidade, porque, afinal, todos se eximem ante o fato de ter sido o procedimento sancionado pelo Presidente da República. Êste é um meio cômodo de o responsável transferir para outrem o que seria de seu dever.

Tal fato ocorre, por vêzes, em conseqüência das disposições legais ou regulamentares e noutras pela forma de encaminhar os assuntos, como também por fôrça de circulares da própria Presidência da República.

Já agora, aproximando-se ràpidamente a época da transferência da sede do Govêrno (21 de abril de 1960), toma o problema maior relêvo, principalmente se considerarmos os múltiplos casos habituais, em que, para simples atos de rotina, se faz mister a ação pessoal do Supremo Magistrado:

$E$ ' chegado o momento de ser ativado o estudo da reforma administrativa, racionalizando-se esta espera, disciplinando-se seus trabalhos e considerando-se que o núcleo central só deverá efetivamente participar de um número de decisões bem reduzido, e principalmente daquelas que afetem a direção geral e dêem caráter normativo. Permitir-se que continue a situação atual é concorrer-se para um fenomenal agravamento das condições reinantes. $O$ tempo gasto em burocracia não se limita à simples tramitação de papéis, Inclui o gasto no percurso das distâncias. Imagine-se o que será se tôda a habitual papelada oriunda dos diversos pontos do país, inclusive desta cidade do Rio de Janeiro, tiver de ser transmitida a Brasília, para colhêr assinaturas que, afinal, são inexpressivas em diversos casos. $E^{\prime}$ de ser notado que, ao atribuir-se 
a uma pessoa o dever de subscrever centenas de papéis, de apenas decisões rotineiras em volumosos processos, não será possível exisir-se dessa autoridade o conhecirnento exato daquilo que assina e nem que despenda seu tempo no estudo apurado das mais variadas matérias. Por certo essa autoridade ou se fia na confiança Jepositada na pessoa que lhe envia o documento ou em secretários próximos que a informam sumàriamente sôbre os assuntos, sendo que êstes mesmos ficam assoberbados e dão vazão ao expediente segundo um critério de confiança ou mesmo político.

Assim, a reforma administrativa terá forçosamente, em vista a evolução por que vem passando o país, as necessidades reais de dinamização administrativa e os males da burocracia tremendamente aumentada, também em tempo, se não forem estabelecidas normas diferentes das atuais quando a Capital estiver interiorizada.

Não deverá essa reforma ser retardada, à espera de mudança da capital para, em face do inevitável, ser analisada atabalhoadamente, quando sabemos que ela deverá ser experimentada antes e melhorada em face do que fôr verificado em sua prática.

$E$ ' uma necessidade imperiosa a fixação de competência de dirigentes, a atribuição da autoridade e da responsabilidade, a par da determinação legal do término de certas práticas na repartição, evitando-se o recurso habitual do Chefe para descartar-se e a tal ponto, que tudo venha a recair na responsabilidade do Presidente da República.

A atual organização administrativa, que vem sendo modernizada a partir de 1937, já não corresponde às atuais necessidades, principalmente pela rápida evolução por que o Brasil vem passando. Hoje podemos fazer comparação e verificações de alterações de vulto de um ano para outro, o que correspondia, no passado, a períodos de décadas.

Não há como negar a rapidez com que se processam hoje os fenômenos sócio-econômicos e os políticos, assim como as mutações violentas, oferecendo o país um panorama diferente a cada ano que se passa. A única conclusão lógica, pois, é a de que a atual estrutura administrativa, como suas normas de funcionamento não só devem ser modernizadas, como terão de ser planejadas para um tipo diferente, mais plástico, que permita acompanhar o ritmo de crescimento que se opera neste período dinâmico de nossa existência. 